\title{
Gambaran Tingkat Resiliensi Masyarakat Desa Sriharjo, Imogiri Pasca Banjir
}

\author{
Nanang Apriyanto ${ }^{1}$, Dody Setyawan ${ }^{2 *}$ \\ ${ }^{1}$ Rumah Sakit Nasional Diponegoro, Semarang, Indonesia \\ ${ }^{2}$ Departemen Ilmu Keperawatan Universitas Diponegoro, Semarang, Indonesia \\ dody.psikfkundip@gmail.com
}

\begin{abstract}
Introduction: The flood disaster with the impact of the isolation of the area causes psychological problems such as anxiety, sadness, anxiety, depression, and impaired adaptation. Continued psychological disorders will cause Post Traumatic Stress Disorder (PTSD). Communities need to have the resilience to be able to manage disasters well through adaptation, maintain basic functions and immediately rise again after a disaster. The purpose of this study was to see the level of resilience of the people of Sriharjo Village, Imogiri after the Flood.

Methods: This research was quantitative research with a survey descriptive design. The population in this study was community of Wunut and Sompok at Sriharjo, Imogiri Village as the most affected areas with a population of 1,573. The sampling technique was purposive sampling and got a sample size of 319 respondents. The data collection technique used a CD RISC-25 questionnaire consisting of 25 statement items, using google form media and contacted via telephone.

Results: The results showed that $60.2 \%$ of respondents had high resilience. Most of the respondents have a high level of resilience to the spiritual influence variable and have a low level of resilience to the positive acceptance of change, and secure relationships variable.

Conclusion: Communities living in disaster-prone areas must be able to become resilient communities by maintaining spiritual influence and increasing positive acceptance of change, and secure relationships.
\end{abstract}

Keywords: Disaster, Psychological Disorders, Resilience Level.

\begin{abstract}
Abstrak
Pendahuluan: Bencana banjir dengan dampak isolasi wilayah menimbulkan dampak gangguan psikologis seperti cemas, sedih, gelisah, depresi dan gangguan adaptasi. Gangguan psikologis yang terus berlanjut akan menimbulkan Post Traumatic Stress Disosder (PTSD). Masyarakat perlu memiliki resiliesi agar mampu mengelola bencana dengan baik melalui adaptasi, mempertahankan fungsi-fungsi dasar dan segera bangkit kembali pasca bencana. Tujuan penelitian ini adalah mengetahui tingkat resiliensi masyarakat Desa Sriharjo, Imogiri pasca Banjir.

Metode: Jenis penelitian ini kuantitatif dengan desain penelitian deskriptif survei. Populasi dalam penelitian ini adalah warga Dusun Sompok dan Wunut, Kelurahan Sriharjo sebagai wilayah paling terdampak banjir dengan jumlah populasi 1.573. Teknik pengambilan sampel dengan purposive sampling mendapatkan jumlah sampel 319 responden. Teknik pengumpulan data menggunakan kuesioner $C D$ RISC-25 yang terdiri dari 25 item pernyataan menggunakan media google form.

Hasil: Hasil penelitian menunjukkan bahwa $60,2 \%$ responden memiliki resiliensi yang tinggi. Sebagian besar responden memiliki tingkat resiliensi yang tinggi pada variabel pengaruh spiritual dan memiliki tingkat resiliensi rendah pada variabel penerimaan yang positif terhadap perubahan dan hubungan baik dengan orang lain.
\end{abstract}


Kesimpulan: Masyarakat yang tinggal di daerah rawan bencana harus mampu menjadi komunitas yang resilien dengan mempertahankan pengaruh spiritual dan meningkatkan penerimaan postif dan hubungan baik dengan orang lain.

Kata Kunci: Becana, Gangguan Psikologis, Resiliensi.

\section{PENDAHULUAN}

Indonesia telah mengalami bencana alam sebanyak 12.366 kejadian, terdiri dari $26,7 \%$ bencana geologi dan $73,3 \%$ bencana hidrometeorologi yang terjadi selama periode tahun 2015 sampai dengan September 2019. Bencana hidrometeorologi yang sering terjadi adalah banjir (2.823 kejadian), tanah longsor (2.258 kejadian) serta kebakaran hutan dan lahan (696 kejadian) (Badan Nasional Penanggulangan Bencana, 2019).

Bencana banjir dapat memberikan dampak berupa fisik, psikologis dan sosial bagi para korbannya. Dampak fisik dapat berupa kematian, luka-luka, kerusakan infrastruktur dan kerusakan lingkungan. Dampak sosial juga bisa terjadi, dapat berupa sikap individualisme, hubungan masyarakat semakin renggang, egois serta merasa ketergantungan pada bantuan (Soulisa, 2019). Dampak psikologis banjir seperti kecemasan, depresi, psikosomatis dan masalah dalam penyesuaian diri (Suwarningsih, Muhafillah, \& Herawati, 2019).

Masyarakat yang mengalami bencana banjir terutama yang memiliki kejadian berulang cenderung mengalami gangguan psikologis berupa depresi ringan sampai berat (Erni \& Kuncoro, 2019). Banjir di Desa Gempolsari, Sidoarjo sebanyak $62 \%$ masyarakat mengalami cemas kategori sedang, dengan reaksi emosional seperti tidak tenang, tidak bahagia, merasa gugup dan gelisah ketika masyarakat berpikir tentang bencana banjir (Purwastuty, 2019). Dampak masalah psikologis yang terus berlanjut akan menjadi Post Traumatic Stress Disorder (PTSD). Gangguan psikologis lanjutan (tiga tahun pasca banjir) di Pakistan tahun
2010 ditemukan 24,7\% mengalami PTSD ringan, 36,3\% PTSD sedang dan 31\% PTSD berat (Aslam \& Kamal, 2016). Kejadian banjir di Garut Jawa Barat tahun 2016 juga menyebabkan 51\% warganya mengalami PTSD (Suwarningsih et al., 2019).

Adanya berbagai dampak psikologis dari kejadian banjir, diperlukan suatu sistem untuk memelihara fungsi dan struktur diri dalam menghadapi gangguan, serta kemampuan sistem untuk mengorganisasi diri yang berhubungan dengan tekanan akibat perubahan yang disebut dengan resiliensi (Louis et al., 2006). Resiliensi dalam konteks bencana adalah kapasitas masyarakat untuk mengelola bencana dengan baik melalui proses adaptasi, mempertahankan fungsifungsi dasar di dalam masyarakat dan kapasitas untuk memulihkan kembali seperti keadaan sebelum bencana (Twigg, 2009).

Hasil studi pendahuluan diperoleh informasi bahwa wilayah paling terdampak banjir tahun 2019 berada di Dusun Sompok dan Dusun Wunut. Adapun di Dusun Sompok objek yang mengalami kerusakan berupa lima kandang sapi hanyut terbawa arus sungai dan 23 rumah mengalami kerusakan. Sedangkan di Dusun Wunut terdapat dua kandang ternak hanyut, dua jembatan hanyut dan satu rusak, tiga rumah rusak, dan empat jalan umum terputus. Dampak psikologis yang dirasakan masyarakat pasca banjir adalah takut dan sedih karena kehilangan rumah atau fasilitas lain yang tidak bisa digunakan. Menurut Kepala Dusun Sompok terdapat seorang warga yang cenderung bingung, suka menyendiri dan 
tampak takut jika membahas masalah banjir. Kondisi warga tersebut berlangsung sampai sekitar sepuluh bulan pasca banjir. Dampak banjir pada masyarakat Desa Sriharjo telah menimbulkan gangguan fisik, sosial dan psikologi serta mengakibatkan sebagian warga teriolasi yang dapat menimbulkan pengalaman traumatik. Penelitian terkait resiliensi korban banjir beberapa sudah dilakukan, akan tetapi setiap daerah mempunyai karakteristik banjir dan dampak yang ditimbulkan berbeda beda baik dampak fisik maupun psikisnya termasuk di daerah Imogiri. Berdasarkan latar belakang permasalahan tersebut, maka rumusan masalah dalam penelitian ini adalah "Bagaimana gambaran Tingkat Resiliensi pada Masyarakat Kelurahan Sriharjo, Imogiri Pasca Banjir".

\section{METODE}

Metode penelitian yang digunakan dalam penelitian ini adalah deskriptif survei yang dilaksanakan pada tanggal 1521 Juli 2020 pada masyarakat Dusun Wunut dan Sompok Kelurahan Sriharjo Kecamatan Imogiri. Jumlah sampel dalam penelitian ini berjumlah 319 responden dengan kreteria inklusi: warga yang masih domisili di lokasi penelitian yang terdampak banjir tahun 2019, umur di atas atau sama dengan 17 tahun dan mampu membaca dan menulis Bahasa Indonesia. Kuesioner penelitian ini menggunakan kuesioner Connor-Davidson Resilience Scale versi 25 (CD RISC-25) yang sudah tersedia dalam versi Bahasa Indonesia dan telah dilakukan uji validitas dengan hasil signifikan yaitu $t$ hitung 0,83 ( $t$ tabel 0,361) sehingga kuesioner dikatakan valid, sedangkan hasil uji reliabilitas menunjukkan koefisien alfa sebesar 0,87 sehingga kuesioner dikatakan reliabel (Connor \& Davidson, 2018). Peneliti juga melakukan uji face validity untuk mengetahui sejauh mana hasil pengukuran tetap konsisten, yaitu dilakukan uji face validity kepada korban banjir di Desa Pendowoharjo terhadap 4 orang yang semuanya menyatakan kuesioner CD RISC-25 dapat dipahami dan dimengerti. Kuesioner penelitian terdiri dari 25 item pernyataan, dalam bentuk skala likert dan menggunakan bantuan google form dan ada yang dengan ditelpon secara langsung. Penelitian ini telah lulus uji etik penelitian dari Komite Etik Penelitian Kesehatan Departemen Ilmu Keperawatan FK UNDIP dengan nomor 111/EC/KEPK/D.Kep/VI/2020. Analisa data dalam penelitian terdiri dari analisa univariat dan hasil uji normalitas diperoleh nilai probabilitas $=0,0$, sehingga data tidak berdistribusi normal serta sebagai cut off point menggunakan nilai median. Selama proses penelitian, peneliti berpedoman pada etika penelitian, yaitu menghormati harkat dan martabat manusia, menjaga rahasia dan privasi responden, menghormati keadilan dan keterbukaan, memperhitungkan manfaat dan kerugian.

\section{HASIL}

Tabel 1. Distribusi Frekuensi Responden berdasarkan Tingkat Resiliensi Masyarakat di Desa Sriharjo Pasca Banjir Juli 2020 (n= 319)

\begin{tabular}{ccc}
\hline Resiliensi & Frekuensi & $(\%)$ \\
\hline Tinggi & 192 & 60,2 \\
Rendah & 127 & 39,8 \\
Jumlah & 319 & 100,0 \\
\hline
\end{tabular}

Berdasarkan tabel 1 menunjukkan bahwa sebagian besar masyarakat berada dalam tingkat resiliensi yang tinggi $(60,2 \%)$. 
Tabel 2. Distribusi Frekuensi Responden berdasarkan Tabulasi Silang antara Tingkat Resiliensi Responden dengan Karakteristik Responden Masyarakat Desa Sriharjo Pasca Banjir Juli 2020 ( $\mathrm{n}=319$ )

\begin{tabular}{|c|c|c|c|}
\hline \multirow[b]{2}{*}{ No. } & \multirow{2}{*}{$\begin{array}{l}\text { Karakteristik } \\
\text { Demografi }\end{array}$} & \multicolumn{2}{|c|}{ Tingkat Resiliensi } \\
\hline & & $\begin{array}{l}\text { Tinggi } \\
\mathrm{f}(\%)\end{array}$ & $\begin{array}{c}\text { Rendah } \\
\mathrm{f}(\%)\end{array}$ \\
\hline \multirow[t]{7}{*}{1.} & Usia & & \\
\hline & $\begin{array}{c}\text { Remaja Akhir } \\
\text { (17-25 tahun) }\end{array}$ & $27(45 \%)$ & $33(55 \%)$ \\
\hline & $\begin{array}{l}\text { Dewasa Awal (26- } \\
\quad 35 \text { tahun) }\end{array}$ & $74(54 \%)$ & $63(46 \%)$ \\
\hline & $\begin{array}{c}\text { Dewasa Akhir } \\
\text { (36-45 tahun) }\end{array}$ & $40(74,1 \%)$ & $14(25,9 \%)$ \\
\hline & $\begin{array}{l}\text { Lansia Awal (46- } \\
55 \text { tahun) }\end{array}$ & $31(88,6 \%)$ & $4(11,4 \%)$ \\
\hline & $\begin{array}{l}\text { Lansia Akhir (56- } \\
\quad 65 \text { tahun) }\end{array}$ & $11(52,4 \%)$ & $10(47,6 \%)$ \\
\hline & $\underset{\text { tahun })}{\text { Manula }}(>\quad 65$ & $9(75 \%)$ & $3(25 \%)$ \\
\hline \multirow[t]{3}{*}{2.} & Jenis Kelamin & & \\
\hline & Laki-laki & $152(74,1 \%)$ & $53(25,9 \%)$ \\
\hline & Perempuan & $40(35,1 \%$ & $74(64,9 \%)$ \\
\hline \multirow[t]{6}{*}{3.} & Pendidikan & & \\
\hline & Tidak Sekolah & $2(100 \%)$ & $0(0 \%)$ \\
\hline & $\mathrm{SD}$ & $10(90,9 \%)$ & $1(9,1 \%)$ \\
\hline & SMP & $64(55,2 \%$ & $52(44,8 \%)$ \\
\hline & SMA & $110(62,9 \%)$ & $65(37,1 \%)$ \\
\hline & Perguruan Tinggi & $6(40 \%)$ & $9(60 \%)$ \\
\hline \multirow[t]{6}{*}{4.} & Pekerjaan & & \\
\hline & Tidak Bekerja & $9(40,9 \%)$ & $13(59,1 \%)$ \\
\hline & Wiraswasta & $62(54,9 \%$ & $51(45,1 \%)$ \\
\hline & Pegawai Swasta & $76(65 \%)$ & $41(35 \%)$ \\
\hline & PNS/TNI/POLRI & $19(76 \%)$ & $6(24 \%)$ \\
\hline & $\begin{array}{c}\text { Petani/Berkebun/ } \\
\text { Beternak }\end{array}$ & $26(61,9 \%)$ & $16(38,1 \%)$ \\
\hline \multirow[t]{3}{*}{5.} & Penghasilan & & \\
\hline & $<$ Rp.1.790.500,00 & $78(58,2 \%)$ & $56(41,8 \%)$ \\
\hline & $\geq$ Rp.1.790.500,00 & $114(61,6 \%)$ & $71(38,4 \%)$ \\
\hline \multirow[t]{4}{*}{6.} & $\begin{array}{l}\text { Riwayat Menjadi } \\
\text { Korban } \\
\text { Bencana }\end{array}$ & & \\
\hline & $1 \mathrm{kali}$ & $3(100 \%)$ & $0(0 \%)$ \\
\hline & 2 kali & $43(44,3 \%)$ & $54(55,7 \%)$ \\
\hline & $\geq 3$ kali & $146(66,7 \%)$ & $73(33,3 \%)$ \\
\hline
\end{tabular}

Tabel 2 menunjukkan resiliensi tinggi pada semua kategori usia kecuali usia remaja akhir, jenis kelamin laki-laki dan riwayat menjadi korban bencana. Sedangkan resiliensi rendah terdapat pada usia remaja dan responden yang tidak memiliki pekerjaan.
Tabel 3. Distribusi Frekuensi Responden Berdasarkan Tingkat Resiliensi Masyarakat Desa Sriharjo Pasca Banjir dengan Sub variabel Resiliensi

\begin{tabular}{|c|c|c|c|}
\hline No. & Sub Variabel & $\begin{array}{l}\text { Resiliensi } \\
\text { Tinggi }\end{array}$ & $\begin{array}{l}\text { Resiliensi } \\
\text { Rendah }\end{array}$ \\
\hline 1. & $\begin{array}{l}\text { Pengaruh } \\
\text { spiritual }\end{array}$ & $94,7 \%$ & $5,3 \%$ \\
\hline 2. & $\begin{array}{l}\text { Kompetensi } \\
\text { pribadi, standar } \\
\text { yang Tinggi dan } \\
\text { Keuletan, }\end{array}$ & $63,9 \%$ & $36,1 \%$ \\
\hline 3. & $\begin{array}{l}\text { Kepercayaan } \\
\text { dalam naluri } \\
\text { seseorang dan } \\
\text { toleransi terhadap } \\
\text { efek yang negatif }\end{array}$ & $59,9 \%$ & $40,1 \%$ \\
\hline 4. & $\begin{array}{l}\text { Kemampuan } \\
\text { mengontrol diri } \\
\text { saat menghadapi } \\
\text { stressor }\end{array}$ & $58,6 \%$ & $41,4 \%$ \\
\hline 5. & $\begin{array}{l}\text { Penerimaan } \\
\text { positif terhadap } \\
\text { perubahan dan } \\
\text { hubungan yang } \\
\text { baik dengan } \\
\text { oranglain }\end{array}$ & $54,5 \%$ & $45,5 \%$ \\
\hline
\end{tabular}

Tabel 3 menunjukkan tingkat resiliensi tinggi masyarakat Desa Sriharjo pasca banjir pada sub variabel pengaruh spiritual $(94,7 \%)$ dan paling rendah pada penerimaan positif terhadap perubahan dan hubungan yang baik dengan orang lain $(54,5 \%)$

\section{PEMBAHASAN}

Tingkat resiliensi pada masyarakat Dusun Sompok dan Wunut, Kelurahan Sriharjo, Kecamatan Imogiri pasca banjir tahun 2019 menunjukkan sebagian besar masyarakat berada pada tingkat resiliensi yang tinggi. Hasil penelitian ini lebih rendah dari hasil penelitian Habibah, Lestari, Oktaviana, dan Nashori (2018) pada masyarakat Dusun Jati, Kelurahan Sriharjo, Kecamatan Imogiri pasca banjir tahun 2017 yaitu masih terdapat tingkat resiliensi masyarakat pada tingkat yang rendah. Bencana banjir tahun 2019 
menimbulkan dampak terputusnya akses jalan dan jembatan sehingga menyebabkan sebagian masyarakat terisolasi. Masyarakat terdampak banjir yang terisolasi lebih rentan mengalami gangguan psikologis seperti takut, sedih, trauma dan depresi (Yayasan Pengabdi Masyarakat (YPM) \& Japan International Cooperation Agency [JICA], 2010). Selaras dengan penelitian Fauziya \& Daulima (2017) pada korban banjir Cemara Kulon memaparkan bahwa warga korban banjir yang terisolir mengalami stress dan putus asa.

Hasil penelitian ini menunjukkan bahwa laki-laki lebih resilien dibandingkan perempuan. Hasil penelitian ini berbeda dengan hasil penelitian yang dilakukan oleh Sandani, Elvira, Susilaningrum, dan Solihati., (2015) pada korban erupsi Gunung Merapi tahun 2010 yang menunjukkan tidak ada perbedaan tingkat resiliensi pada laki-laki dan perempuan. Perempuan merupakan kelompok rentan dengan keahlian fisik yang terbatas sehingga tidak memiliki kemampuan bertahan hidup dengan baik ketika terjadi bencana (International Federation of Red Cross and Red Crescent Societies [IFRC], 2010). Laki-laki cenderung memiliki tingkat resiliensi yang tinggi dikarenakan lebih mudah beradaptasi, tanggap, berpikir rasional dan lebih dominan dalam pengambilan keputusan saat banjir (Nufus \& Husna, 2017; Pattipeilohy \& Mardiatmoko, 2019).

Hasil penelitian ini menunjukkan masyarakat yang menjadi korban bencana minimal satu kali, cenderung memiliki tingkat resiliensi yang tinggi. Hasil ini selaras dengan Akbar (2016) yang menemukan salah satu faktor protektif mampu meningkatkan resiliensi adalah pengalaman bencana yang pernah dialami (disaster experience).

Tingkat resiliensi pada remaja dipengaruhi oleh beberapa faktor yaitu individu, keluarga dan komunitas (Everall, Altrows, \& Paulson, 2006). Margareth
(2016) memaparkan bahwa remaja dengan self-esteem yang rendah cenderung memiliki resiliensi yang rendah. Ariyati, (2018) meneliti keluarga miskin dan memaparkan bahwa remaja yang tidak memperoleh dukungan keluarga dengan baik cenderung memiliki resiliensi rendah. Selain faktor inidividu dan keluarga, dukungan komunitas yang buruk akan mengakibatkan rendahnya resiliensi pada remaja korban banjir. Heppi (2018) memaparkan bahwa semakin rendah dukungan sosial teman sebaya pada remaja korban banjir maka semakin rendah tingkat resiliensinya.

Tingkat resiliensi yang rendah pada masyarakat Desa Sriharjo juga terdapat pada sebagian responden yang tidak memiliki pekerjaan dan sebagian responden dengan penghasilan kurang dari Upah Minimun Regional (UMR). Sembiring \& Dharmawan (2014) memaparkan bahwa semakin tinggi jumlah pendapatan maka semakin tinggi tingkat resiliensinya.

Hasil penelitian tingkat resiliensi masyarakat Desa Sriharjo pasca banjir berdasarkan sub variabel menunjukkan paling tinggi pada variabel pengaruh spiritual dan menunjukkan paling rendah pada penerimaan positif terhadap perubahan dan hubungan dengan orang lain. Masyarakat Desa Sriharjo memiliki resiliensi paling tinggi pada sub variabel pengaruh spiritual yang artinya masyarakat merasa yakin akan kehadiran Tuhan setiap waktu. Fidinillah (2018) menunjukkan semakin tingginya religious coping maka tingkat resiliensi juga semakin tinggi. Dengan religious coping yang baik, korban banjir dapat menilai kembali ujian yang diberikan Tuhan secara positif, percaya diri dan segera bangkit dari keterpurukan akibat banjir, berpikir optimis, serta percaya bahwa Tuhan dengan umat-Nya.

Sub variabel berikutnya adalah kompetensi pribadi, standar yang tinggi dan keuletan yang digunakan untuk 
menilai kemampuan individu untuk mencapai tujuan walaupun sedang menghadapi tekanan atau stressor. Hasil wawancara dengan Kepala Dusun Wunut, Kelurahan Sriharjo memaparkan bahwa pengalaman banjir tahun 2017 memberikan pengalaman berharga bagi warga dalam upaya siap siaga banjir dan keuletan mamantau kodisi alam sekitar seperti awan mendung dan gelap serta ketinggian air sungai Oyo yang meningkat. Hasil penelitian korban banjir Bojongloa, Kabupaten Bandung menunjukkan bahwa masyarakat memiliki kemampuan memperkirakan datangnya banjir dan tindakan segera yang harus dilakukan warga berdasarkan pengalaman banjir sebelumnya. Kemampuan tersebut seperti melihat cuaca mendung dan gelap (pontensi hujan lebat), ulet memantau kondisi cuaca di daerah yang lebih tinggi dan menetapkan waktu 1 jam pasca hujan lebat sebagai waktu untuk evakuasi (Habiba, Nurdin, \& Muhamad, 2017).

Sub variabel berikutnya adalah kepercayaan dalam naluri seseorang dan toleransi terhadap efek yang negatif yang digunakan untuk menilai kemampuan individu dalam menghadapi bencana yang cenderung bersikap tenang, hati-hati, cepat melakukan koping terhadap stressor dan tetap fokus pada tujuan. Masyarakat Desa Sriharjo merasa yakin dengan potensi yang dimiliki, walaupun menghadapi banjir masyarakat tetap yakin mampu bangkit kembali. Afdilla (2019) memaparkan bahwa masyarakat korban bencana erupsi Gunung Merapi tetap bersikap tenang, tidak gegabah dan telah mempersiapkan kebutuhan yang dapat digunakan jika sewaktu-waktu ada instruksi untuk mengungsi.

Sub variabel berikutnya adalah kemampuan mengontrol diri saat menghadapi stressor yang digunakan untuk menilai kemampuan individu dalam mengendalikan emosi dan perilaku saat menghadapi bencana. Fauziya dan
Daulima (2017) memapaparkan bahwa korban banjir dengan kecerdasan emosi tinggi mempunyai kemungkinan 8,625 kali lebih besar memiliki resiliensi tinggi. Kurniawan, Muttaqin, dan Utomo (2018) meneliti korban bencana tanah longsor di Kudus, Jawa Tengah dan memaparkan bahwa agar dapat mampu mengontrol emosi yang baik, individu harus bersikap tenang dan berusaha menghilangkan kecemasan yang berlebihan. Regulasi emosi yang baik pada masyarakat korban banjir dipengaruhi oleh usia responden, dimana semakin bertambahnya usia maka pengendalian emosi lebih terkontrol. (Nufus \& Husna, 2017). Begitu pula dengan hasil penelitian korban banjir di Desa Sriharjo yakni mayoritas rentang usia dalam kategori tinggi, kecuali pada rentang usia remaja yang masih terdapat kategori rendah sebesar 55\%. Individu yang telah dewasa cenderung mampu mengontrol emosi dan bertingkah laku yang baik saat menghadapi banjir (Hurlock, 2006).

Hasil penelitian pada masyarakat Desa Sriharjo masih ditemukan hampir setengah responden dengan tingkat resiliensi pada sub variabel penerimaan positif terhadap perubahan dan hubungan yang baik dengan orang lain berada pada tingkat yang rendah. Hasil penelitian ini lebih baik daripada hasil penelitian Titi, Sefianmi, dan Mentari (2016) yang menunjukkan bahwa hampir tiga perempat responden dengan kemampuan memandang aspek positif dalam kategori rendah. Korban banjir Dayeuhkolot memandang banjir akan selalu terjadi diwilayahnya dan banjir akan merendam pemukiman. Hasil penelitian tersebut menunjukkan bahwa belum adanya sikap positif dalam menghadapi stressor yang ada terutama pasca banjir. Safitri \& Khairat (2017) meneliti korban bencana alam dan memaparkan bahwa ada $47 \%$ orang yang mengalami stress dikarenakan pemikiran negatifnya. 


\section{KESIMPULAN DAN SARAN}

Hasil penelitian menunjukkan bahwa tingkat resiliensi masyarakat Desa Sriharjo, Imogiri pasca banjir masih banyak yang rendah. Sebagian besar masyarakat memiliki resiliensi tinggi pada variabel pengaruh spiritual, namun rendah pada variabel penerimaan yang positif terhadap perubahan dan hubungan baik dengan orang lain.

Masyarakat yang tinggal didaerah rawan bencana harus mampu menjadi komunitas yang resilien dengan mempertahankan pengaruh spiritual dan meningkatkan penerimaan postif dan hubungan baik dengan orang lain.

\section{DAFTAR PUSTAKA}

Afdilla, N. H. (2019). Modal sosial dalam upaya pengurangan resiko bencana dan peningkatan resiliensi komunitas (Studi Kasus Desa Kepuharjo, Cangkringan, Sleman). Universitas Islam Indonesia Yogyakarta. Diperoleh dari https://dspace.uii.ac.id/handle/123456 $789 / 16237$

Akbar, Z. (2016). Post-traumatic growth: Long term psychological conditions among disaster survivors in Yogyakarta-ßIndonesia. University of Leipzig.

Ariyati, P. C. (2018). Hubungan antara dukungan keluarga dengan resiliensi pada remaja di keluarga miskin. Universitas Muhammadiyah Malang. Diperoleh dari http://eprints.umm.ac.id/42654/1/SKR IPSI_PCA_PFSI_206.pdf

Aslam, N., \& Kamal, A. (2016). Stress, anxiety, depression, and posttraumatic stress disorder among general population affected by floods in
Pakistan. Pakistan Journal of Medical Research, 55(1), 29-32.

Badan Nasional Penanggulangan Bencana. (2019). Jumlah kejadian bencana Indonesia periode 2016-2019. Diperoleh dari http://bnpb.cloud/dibi/grafik1a

Connor, K. M., \& Davidson, J. R. T. (2018). Connor-Davidson Resilience Scale ( CD-RISC ) (C) Manual, 1-169. Diperoleh dari www.cd\%0Arisc.com.

Erni, S., \& Kuncoro, J. (2019). Tingkat depresi pada masyarakat Semarang Utara yang mengalami banjir rob. Journal of Chemical Information and Modeling, 53(9), 1689-99. doi: 10.1017/CBO9781107415324.004

Everall, R. D., Altrows, K. J., \& Paulson, B. L. (2006). Creating a future: A study of resilience in suicidal female adolescents. Journal of Counseling \& Development, 84(4), 461-470. doi: 10.1002/j.1556-6678.2006.tb00430.x

Fauziya, L. I., \& Daulima, N. H. C. (2017). Hubungan kecerdasan emosi dengan resiliensi penyitas banjir. Jurnal Keperawatan Indonesia, 20(3), 148157. doi: 10.7454/jki.v20i3.624

Fidinillah, Q. (2018). Hubungan religious coping dan resiliensi pada remaja korban bencana banjir dan tanah longsor di Pacitan. Universitas muhammadiyah malang. Diperoleh dari

http://eprints.umm.ac.id/40572/1/Skri psi.pdf

Habiba, N., Nurdin, M. F., \& Muhamad, R. A. T. (2017). Adaptasi sosial masyarakat kawasan banjir di Desa Bojongloa Kecamatan Rancaekek. 
Pemikiran dan Penelitian Sosiologi, 2(1), 40-58.

Habibah, R., Lestari, S. D., Oktaviana, S. K., \& Nashori, F. (2018). Resiliensi pada penyintas banjir ditinjau dari tawakal dan kecerdasan emosi. Jurnal Psikologi Islam Dan Budaya, 1(1), 29. doi: 10.15575/jpib.v1i1.2108

Heppi, S. (2018). Hubungan dukungan sosial teman sebaya dan resiliensi remaja korban bencana di Pacitan. Universitas Muhammadiyah Malang. Diperoleh dari http://eprints.umm.ac.id/40523/1/Skri psi.pdf

Hurlock, E. B. (2006). Psikologi perkembangan. Jakarta: Erlangga.

International Federation of Red Cross and Red Crescent Societies (IFRC). (2010). World disasters report 2010urban risk. Diperoleh dari https://www.ifrc.org/en/publicationsand-reports/world-disastersreport/wdr2010/

Kurniawan, Y., Muttaqin, I., \& Utomo, P. B. (2018). Resiliensi pada korban longsor di Rahtawu Kabupaten Kudus. Prosiding Seminar Nasional Peran Ilmu Psikologi dalam Pengurangan Risiko Bencana. Diperoleh dari http://ejournal.unbi.ac.id/index.php/se mnaspsikologibencana/article/view/76

Louis, L., Anderies, M., Campell, B., Folke, C., Hatfield-Dodds, S., Hughes, T. P. ... Wilson, G. (2006). Governance and The Capacity to Manage Resilience in Regional Social-Ecological Sistems. Ecologi and Society, 11(1), 19.

Margareth, V. (2016). Hubungan antara self esteem dengan resiliensi pada siswa sekolah menegah pasca banjir dan tanah longsor di Daerah Batu Gajah Ambon. Universitas Kristen Satya Wacana. Diperoleh dari https://repository.uksw.edu/bitstream/ 123456789/10027/2/T1_802011085_ Full text.pdf

Nufus, R., \& Husna, C. (2017). Resiliensi masyarakat pasca bencana banjir. Jurnal Ilmiah Mahasiswa Fakultas Keperawatan, 2(3), 1-11.

Pattipeilohy, D. E., \& Mardiatmoko, G. (2019). Resiliensi masyarakat terhadap banjir (Studi kasus Desa Batu Merah Kecamatan Sirimau Kota Ambon). Jurnal Agribisnis Kepulauan, 7(1), 88-105.

Purwastuty, I. (2019). Kecemasan masyarakat terhadap bencana banjir bandang di Desa Batuganda Kecamatan Lasusua Kabupaten Kolaka Utara. Jurnal Mimbar Kesejahteraan Sosial, 1-10.

Safitri, N., \& Khairat, I. (2017). Konseling trauma oleh Ikatan Konselor Indonesia (IKI) untuk korban bencana alam gempa bumi (Studi di Kabupaten Pidie Jaya). Jambore Konselor 3 (Vol. 3, pp. 74-84). Sigli: Universitas Jabal Ghafur. Diperoleh dari

https://www.gci.or.id/assets/papers/ja mbore-konseling-3-2017-194.pdf

Sandani, A. P., Elvira, I. A., Susilaningrum, R., \& Solihati, Y. M. (2015). Perbedaan resilience ditinjau dari jenis kelamin dan big five personality pada korban pasca erupsi Gunung Merapi tahun 2010. Universitas Ahmad Dahlan.

Sembiring, S. T., \& Dharmawan, A. H. (2014). Resiliensi nafkah rumah tangga petani di kawasan rawan 
bencana rob Kecamatan Kampung Laut Kabupaten Cilacap. Jurnal Sosiologi Pedesaan, 2(1), 30-42.

Soulisa, M. S. (2019). Perubahan sosial masyarakat Negeri Hena Lima Leihitu Kabupaten Maluku Tengah. Dialektika, 12(01), 57-70. doi: 10.33477/dj.v12i1.791

Suwarningsih, S., Muhafillah, I., \& Herawati, T. M. (2019). Perubahan kondisi psikososial dan spiritual pada korban PTSD (post traumatic stress disorder). Jurnal Ilmiah Kesehatan, 11(1), 1-11. doi: 10.37012/jik.v11i1.62

Titi, D. S., Sefianmi, D., \& Mentari, A. (2016). Profil resiliensi kepala keluarga yang menjadi korban banjir di Desa Dayeuhkolot Kabupaten Bandung. Ilmiah Psikologi Reliabel, 8(3), 24-52.

Twigg, J. (2009). Characteristics of a disaster-resilient community (2nd ed.). London: University College London.

Yayasan Pengabdi Masyarakat (YPM), \& Japan International Cooperation Agency (JICA). (2010). Penelitian dasar dan persiapan untuk sub proyek sistem peringatan dini dan evakuasi dini di Kabupaten Jember. Diperoleh dari https://www.jica.go.jp/project/indones ian/indonesia/0800040/materials/pdf/ outputs_19_01.pdf 